\title{
Domesticating the Democratic Deficit? The Role of National Parliaments and Parties in the EU's System of Governance
}

\author{
Richard Bellamy and Sandra Kröger
}

The Lisbon Treaty (LT) grounds the European Union (EU) in the principles of political equality and representative democracy. It also acknowledges the role national parliaments play in realising these norms within the EU's system of governance-the first time they have been mentioned in the main body of the Treaty on European Union (TEU) - and introduced the Early Warning Mechanism(EWM) as a means for national parliaments (NPs) to be involved in EU policymaking. This article analyses the normative and empirical connections between political equality and representative democracy at the domestic level, and the ways they are embodied in parliamentary elections between competing parties. It then assesses how far these links continue to operate in the domestic debate of EU affairs before undertaking a first evaluation of the use NPs have made of the Early Warning Mechanism (EWM). We argue that in many respects theyhave been undermined by the integration process, which has reduced the capacity of national representative institutions to perform the tasks assigned to them by the Treaty.

\section{Introduction}

The Euro crisis has brought to the fore the continued significance of the domestic democratic legitimation of European policy initiatives. In particular, it has revealed the importance of national parliaments (NPs) in this process. Bailout packages have required ratification by all NPs, which have reasserted their right to monitor government budgetary decisions notwithstanding the provisions of the new fiscal compact. NPs have also begun to exercise the new powers within the EU's political system that they acquired in the Lisbon Treaty.

Article 10 of the post-Lisbon Treaty on European Union (TEU) affirms the EU to be founded on representative democracy, with political equality as its normative core (Lord and Pollak 2010: 126). Article 10 (2) links these standards directly to parliamentary government, with reference to not only the European Parliament (EP) but also NPs, mentioning them for the first time in the main text of the Treaty. As Article 10 (2) proclaims, 'Citizens are directly represented at Union level in the European Parliament. Member States (MS) are represented in the European Council by their Heads of State or Government and in the Council by their governments, themselves democratically accountable either to their national parliaments, or to their citizens.' Article 12 details the basic rights and functions of NPs in EU matters and introduces an 'Early Warning Mechanism' (EWM) that assigns national legislatures the right to scrutinize proposed EU decisions and initiatives for compliance with the principles of subsidiarity and proportionality. Furthermore, NPs can have a collective legislative influence in that a majority of them may force, by way of a so-called 'orange card', an early vote on an 
EU legislative proposal in the Council and the EP. They are also now involved in the evaluation of measures taken within the area of freedom, security and justice (Articles 70, 85, 88), may block Treaty changes under the simplified revision procedures (Article 48) and must be informed of new applications to join the EU (Article 49). NPs have therefore become actors in their own right in EU policy-making.

These provisions mark a shift in the understanding of democracy in the EU. They continue a trend going back to the Maastricht Treaty and the debate on the EU's democratic deficit that have seen the empowerment of NPs in EU affairs as one possible mechanism for tackling this issue. Previous measures included a legally binding 'Protocol on the role of National Parliaments in the European Union' (PNP) which accorded NPs the right to receive information on EU affairs, demanded that there be a six week period between issuing a legislative proposal and its adoption by the Council, and introduced rules for the cooperation between NPs and the European Parliament (EP), not least in the context of COSAC ${ }^{1}$. This paper explores whether NPs are capable of living up to the normative role assigned to them, including an early assessment of the use of the new EWM.

Hitherto, NPs have been marginal within scholarly debates about the democratic deficit of the EU. On the one hand, such a domestic deficit either passed unnoticed or the possibilities of remedying it were conceived as being beyond the boundaries of the nationstate, through enhancing the competences of the EP (Hix 2008). We leave that latter possibility to one side for the purposes of this article. On the other hand, it has been argued that the need for democratic oversight of EU policy-making in general, and the role NPs might play in it in particular, is marginal at best. Scholars taking this line maintain that competences can be neatly divided between the EU and its MS (Majone 2001; Moravcsik 2002).The EU is merely responsible for the creation of the internal market and to achieve this task can be justifiably isolated from partisan politicization and electoral competition. The MS need only to legitimize this project by consulting domestically and negotiating the national interest at the EU-level. However, this perspective rests on a thin notion of the EU's legitimacy which assumes that as long as market creation is efficiently and effectively organized and realized and has been legitimised by national elites as in the national interest, the agent of that project will itself be legitimate. We could not disagree more. Not only is the EU in need of its own legitimacy given it exercises power over states and citizens, but also the progressive realization of the internal market is increasingly constraining MS in their range of available policy options, thereby raising the stakes for the domestic legitimation of the EU.

\footnotetext{
${ }^{1}$ Conférence des Organes Spécialisés dans les Affaires Communautaires. COSAC is the Conference of the committees of the NPs dealing with European affairs as well as representatives of the EP.
} 
The continued importance of domestic representative institutions - parliaments and parties - in EU matters is undeniable, therefore. The key question is how far they are still capable of performing the roles ascribed to them by the normative theory of representative democracy implicit in the LT. As a number of scholars have noted, there is growing disaffection with the capacity of traditional institutions of representative democracy to represent their citizens - witness the near universal decline in electoral turnout. Worse, the EU may even be contributing to this state of affairs by weakening parliamentary control of the executive, including by delegating important regulatory roles to non-majoritarian bodies, such as the European Court of Justice (ECJ) and European Central Bank, which are not even subject to democratic oversight at the European level by the European Parliament (EP) (Bellamy 2010). As a result, far from supporting representative democracy - at least at the national level - the EU may be promoting a shift not just to 'policy without politics' (Schmidt 2006) but even to 'polities without politics', a form of 'audience democracy' (Manin 1997), 'post democracy' (Crouch 2004) or 'post-parliamentary governance' (Andersen and Burns 1996).

Not all analysts consider these developments to have gone so far, or - to the extent they have occurred - to be unjustified (Moravcsik 2002). They see the international constraints on national democracies as paralleling the domestic constraints adopted by most constitutional democracies (Keohane, Macedo and Moravcsik 2009). Government for the people need not require government by the people - indeed the second can on occasion subvert the first, and the EU operates primarily in areas where this proves to be the case (Scharpf 1999). However, others are not so sanguine about the EU's undermining of domestic 'input' democracy and dispute the degree to which it has delivered 'output' democracy (Mair 2011; Scharpf 2011). This paper explores how far the EU has indeed undermined representative democracy at the national level; the extent to which such moves might in any case be justified, and whether the new provisions for national parliaments in the LT offer a means for mitigating such a change.

We shall proceed as follows. Section 2 lays out how political equality connects to representative democracy, and the ways parliaments and parties realize these connections. We identify reasonable disagreement as underlying the link between political equality and representative democracy. It explains the need for a process whereby citizens can exercise equal control and influence over politicians and indirectly over the programmes they pursue in order for them to be shown equal concern and respect. We also consider the circumstances when political equality might require that representative democracy be constrained or 
overridden. Section 3 looks at the weakening of national parliaments and political parties as mechanisms for either reasonable disagreement about or (indirect) influence and control over issues of European governance. Section 4 assesses their response, including an analysis of the EWM. Section 5 concludes by summarizing the analysis.

\section{Political Equality and Representative Democracy}

We remarked above how the TEU links representative democracy to political equality. On this account, the core rationale for democracy lies in ensuring collective policies and institutions treat the citizens who they serve with equal concern and respect (Bellamy 2010). Equal concern entails that the interests of all citizens ought to be equally promoted. Equal respect involves according equal weight to their opinions and beliefs. Underlying both these requirements is the thought that no person or class of persons should be thought of as being the inherent superior of another, entitled to use others as a means to their own ends and rule over them in an arbitrary way. However, we shall argue that the justification for equal participation in a democratic process stems not from political equality alone, but additionally involves the existence of reasonable disagreement over what is being decided. Meanwhile, representative democracy substitutes an equal degree of electoral control and influence over decision-making for direct participation in making decision, with parliamentary systems involving regular elections between competing parties the most realistic mechanisms for realizing political equality and reasonable disagreement through a system of electoral authorization and accountability (Strøm et al. 2003).

Democracy can be evaluated for its compatibility with equal concern and respect with regard to either the process of decision-making or the substance and impact of the decisions themselves. The democratic process may be valued either instrumentally for its conduciveness to produce democratic outputs, or intrinsically as valuable in and of itself. Those theorists inclined to stress the intrinsic virtues of democracy do so in part because they contend that decisions regarding the nature of democratic outcomes are a matter of reasonable disagreement and prone to personal bias and fallibility (Christiano 1996; Weale 2007). Modern societies are pluralist, complex and open. Their members hold diverse and often conflicting views and interests, and will be naturally partial towards their own opinions and welfare, be it due to self-interest or the inevitable limitations and differences of their knowledge and experience. Such societies develop in unexpected and unpredictable ways, due 
to the human capacity for conceptual innovation and changing needs and preferences. All these circumstances create reasonable disagreements about the public interest given that people will be likely to assess evidence and weigh moral and political values differently. Most public policies are subject to numerous unknown and often unforeseeable variables that make their effects a matter of informed guess work at best, thereby allowing for considerable empirical disagreement even among experts - as when economists dispute the pros and cons of raising or lowering interest rates at any given time. Likewise, there can be differences over the normative evaluation of empirical evidence, both because of the complicated nature of the empirical data itself and the variety of normative considerations likely to be involved, each possessing a different force (Rawls 1993: 55-7).

The existence of reasonable disagreement across nearly all policy areas creates the 'circumstances' for democratic politics (Waldron 1999: 107-13; Weale 2007: 12-18). The authority and legitimacy of democracy rests on its offering a fair and impartial mechanism for handling such disagreements in ways consistent with political equality. For it gives all an equal say in shaping the common rules, goods and decisions that frame their social interactions and opportunities. Even though particular individuals may continue to disagree with the collective decision, the fact that they have been able to defend their interests and opinions on the same basis as everyone else gives them a reason to accept it. Indeed, this circumstance offers good - if not perfect - grounds for regarding such a process as instrumentally democratic as well. For if the process of decision-making has been conducive to showing citizens equal concern and respect, then, in the absence of objective criteria, it offers the only heuristic available for ensuring the interests of all citizens are considered equally. Of course, there are certain values, such as fundamental rights, and some scientific and technical knowledge, about which disagreement would be unreasonable. In these cases the reasons for democracy may be largely instrumental and prudential - to ensure that those charged with upholding these values or acting on this knowledge do not abuse their position. However, as debates about privacy legislation or nuclear power indicate, it is also more than likely that citizens can and will reasonably disagree - for all the reasons noted above - about those policies best suited to protecting these values or that follow from this knowledge.

A representative system combining one person, one vote and majority rule in fair and regular elections between parties competing to send representatives to a Parliament and form a government, emerged in the late eighteenth century as the most plausible practical instantiation of the ideals of a democratic process for a mass electorate (Hobson 2008: 451). This arrangement replaced direct and equal participation in decision-making with an indirect 
yet equal voice in the authorising of decision-makers and holding them to account. Regular elections indicate that power is conditional and its abuse can be sanctioned, rendering politicians responsive to the electorate. Parties provide the means to organize voters and link them to politicians and policies. Electoral campaigns force parties to compete in recruiting the support of a majority by putting forward a manifesto that aggregates voters' preferences into a prospective programme of government with maximum electoral appeal (Auel and Benz 2005: 375). Within parliament, the vast majority of representatives then vote along party lines, with the executive being drawn from the leadership of the party or coalition of parties that command the majority of seats in the legislature. The result is a long chain of indirect delegation, whereby voters delegate the manifesto's formulation to parties and its implementation to the elected party representatives in parliament, members of parliament delegate in their turn to parliamentary majorities, parliamentary majorities to a prime minister, and the prime minister to cabinet and cabinet ministers to civil servants (Neto and Strøm 2006: 632). In this way, decision-makers are provided with information from millions of citizens, who indirectly influence and control their policy choices and offer feedback on and have the possibility of contesting the resulting policies, prompting politicians to respond to their disparate and changing preferences and circumstances.

As such, parliamentary elections can be regarded as offering a reasonable reflection of the balance of preferences within the electorate. Majority rule provides a fair process that shows all voters equal respect (May 1952), while party competition within a one dimensional, Left-Right, electoral space leads to convergence on the median voter, whose preferences match those of the Condorcet winner (Ordeshook 1986: 254-67), thereby motivating equal concern. Moreover, they also afford protection for minorities, at least in pluralist societies. Because an electoral majority is built from minorities and prone to cycling coalitions, a ruling group will do well not to rely on a minimal winning coalition and to exclude other groups entirely. Consequently, either a currently excluded minority has a good chance of being part of a future winning coalition, or - for that very reason - is likely not to be excluded entirely by any winning coalition keen to retain its long-term power (McGann 2004: 56, 71). Finally, electoral competition recognises reasonable disagreement, reflecting the various cleavages dividing the electorate that might lead them to evaluate policies and their impacts in different ways. It also allows for the possibility that policies may fail, have unintended and unwanted consequences or not to be implemented correctly, or no longer be acceptable to the electorate due to changes in their preferences. The fact that governments must always face an opposition with an electoral incentive to point to the empirical and normative weaknesses and failings of 
its programme, promotes democratic debate and makes it necessary for them to 'hear' and 'harken to' 'the other side' about any policy.

However, no electoral system is infallible. There may be defects in both the process and the outputs that lead them to depart from political equality. All domestic democratic systems constrain the power of national parliaments and parties to some degree. Some commentators argue that the EU simply extends and perfects these constraints (Keohane, Macedo and Moravcsik 2009). For example, a dispersed and hard to organize minority may consistently fail to have any impact at all on policy. By contrast, an electorally salient yet unrepresentative minority in a marginal seat may have a disproportionate influence as may certain well placed special interests. Or a majority might for reasons of prejudice actively oppress a minority. Likewise, ignorance or myopia might lead the electorate to sacrifice its own or the political community's long term interests for short term gain. These potential problems have led most parliamentary systems to adopt a variety of constitutional constraints on the democratic process, such as the judicial review of legislation to protect minority rights, and to isolate certain technical policies from electoral pressures where these are thought to produce perverse results, such as having interest rates set by central banks to hinder governments manipulating them to create a boom at election time with adverse long term consequences for the economy.

Though common, such measures are themselves contentious. They may be justified as generating more democratic outputs than a standard democratic process could, yet if - as we suggested - no clear epistemological warrant for this claim exists other than such a process, then such justifications will prove hard to substantiate in an unequivocal way and remain subject to dispute. Nevertheless, in recent times there has been an increasing use of such nonmajoritarian mechanisms, setting up a potential conflict between 'responsive' and 'responsible' government (Mair 2009). At the same time, the capacity of parties and hence parliaments adequately to represent their populations has also come under pressure. Within Europe, the growth of non-majoritarian mechanisms, on the one side, and the erosion of responsive government, on the other, have been associated with the impact of the EU. Certain commentators regard this international extension of liberal constraints on national democratic decision-making as unwarranted and preventing domestic democratic systems from airing legitimate reasonable disagreements and exercising an appropriate degree of control over their governments (Scharpf 2009; Bellamy 2010). In what follows, we assess this thesis and its consequences for the role now accorded NPs and parties within the system of European governance. 


\section{The Weakening of Domestic Representative Institutions}

As we noted in the last section, parliaments have a public mandate from voters to legislate and to control the executive. De facto, their institutional core consists of the government (which controls the agenda and formulates policy proposals), the parliamentary majority (which accepts or rejects these proposals), and the parliamentary opposition (assuring public deliberation, the generation of political alternatives and control). Democratic legitimacy results from the electoral competition between the different parties who form the majority and the opposition. This leads rival politicians to offer the electorate different programmes and renders them accountable for their actions. Though the practices and institutions of parliamentary democracy vary from one Member State to another, all possess these core features.

In the context of the EU, though, this fairly clear domestic role-distribution between government, parliament and opposition gets blurred. Neither the government nor the parliament has direct influence over the European agenda. It might be objected that national governments do enjoy a high degree of control over the agenda at the Union level, and that they are, in turn, electorally accountable for how they exercise that control. After all, nothing much can happen at the Union level without being sanctioned by the Treaties or periodic meetings of the European Council, which now has responsibility for the strategic direction of the EU. However, governments hardly ever have electoral authorization for specific Union policies, nor can they or the parliaments initiative legislation. Meanwhile, the powers of accountability of the opposition as well as of parliament more generally are weakened, as we will detail below.

Not surprisingly, the 1990s witnessed the emergence of a 'deparliamentarisation' thesis in which NPs emerge as the main 'losers' of European integration (Maurer and Wessels 2001). Not all commentators have agreed with this assessment, believing that in some respects NPs rose to the challenge to become more effective in their scrutiny of executives (Raunio and Hix 2000: 143). However, other analysts are more pessimistic (Mittag and Wessels 2003: 433)They not only note the transfer of policy-making to the EU and the resulting loss of control and influence of NPs and hence of their electorates, but also the strengthening of executives in EU policy-making and the consequent informational asymmetries between the 
legislature and the executive (Auel and Benz 2005: 373). NPs may have acquired new scrutiny powers, but as we shall see their capacity to employ them has often been limited. As a result, NPs are said to 'suffer from a lack of authoritative power over transnational policymaking' (Schmidt 1999: 25). Instead, executives largely perform the legislatures' functions within EU policy-making.

What about parties? As Schattschneider famously remarked (1942: 1), 'modern democracy is unthinkable save in terms of political parties'. Yet, there exists considerable dissatisfaction in European democracies with the current practices and processes of political representation, and particularly with political parties. Across Europe, albeit to differing degrees, there has been a steady, decades long decline in electoral turnout, falling party membership and identification, greater volatility in voter preferences and, hence electoral outcomes, greater difficulty in obtaining and sustaining majority support for governments, a decrease in trust in politicians, parties and political institutions in general, a diminution in the centrality of parliament, and increased devolution of authority to administrative bodies (Schmitter 2009). Are any of these phenomenons related to the European integration process? The literature tells us: not directly, but indirectly (Ladrech 2009; Mair 2007). Not directly, as there are no European directives or guidelines to which parties have to adapt. Also, in contrast to civil society organizations, the EU is not an attractive opportunity structure as there are no resources or potential partisan allies to be gained. Indirectly, however, parties are affected in various ways by the multi-level game, as we will see.

Seven factors have proved particularly important in undermining political equality by reducing the expression of reasonable disagreement and constraining the processes of authorisation and accountability. The following three factors have reduced the scope for disagreement:

(1) First, the transfer of competences to the EU, particularly in fields such as trade or agricultural policy, leaves parliaments, governments and parties little to decide in these areas. Member states have to adopt the acquis communautaire, and they have to comply with ECJ law. True, in most cases a political decision was taken at some stage to transfer competences to the EU (though with the increased importance of qualified majority voting (QMV) in the Council, an MS could potentially have voted against a given transfer). However, once a competence has been transferred to the EU, it is there to stay and taken out of the MS' - and their parties' - primary sphere of influence. Of course, a degree of manoeuvre exists with regard to how EU measures are enacted into domestic legislation. Nevertheless, the EU has 
played a major role in limiting the available 'policy space' for competing parties (Mair 2007) and governments.

(2) The constitutional bias in the Treaties gives priority to the completion and realization of the internal market (Scharpf 1999: 54-58). Consequently, the 'policy repertoire' available to parties - and governments - has been diminished, thereby reducing the possibilities for them to disagree and propose alternatives (Mair 2007). The EU thereby also restricts the range of policy options that are possible within those fields that can still be influenced by domestic politics. Given that the acquis prioritizes the realization of the internal market, parties and especially governments, can only reasonably develop those policies which can be shown to be in line with the four freedoms of the internal market unless they want to risk being taken to Court either by the Commission or by private interests. The ways the primacy of EU law can clash with domestic democratic and / or welfare traditions became clear in the context of the Viking and Laval cases (Joerges 2010) and will be reinforced under the terms of the new European Fiscal Compact. The restriction of the available policy alternatives harms the norm of political equality by not allowing all relevant preferences to be treated with equal concern and respect because of a restriction in the area of reasonable disagreement.

(3) Both the above constraints have been further reinforced by the supremacy and direct effect of EU law as interpreted and upheld by the ECJ and by its claims to 'competence-competence' in deciding whether it may legitimately override national constitutional objections or not. As a result, parliamentary attempts to disagree with the integration process risk becoming de jure unreasonable. They have no choice but to adapt to and implement EU law, even in those cases where ECJ interpretations may be thought to extend EU competences in ways that appear to run counter to the directives approved by national governments. This has occurred in areas related to EU citizenship or freedom of movement (Scharpf 2009) and could occur in the event of the ECJ fining a MS for failing to meet the terms of the fiscal compact.

The net effect of these three factors is a reduction in the policy instruments and political alternatives that national governments - and thereby parliaments and parties - can offer to voters, which in turn decreases electoral competition. As a result, elections become less decisive, and their value decreases. In turn, parties, attempt to avoid the politicisation or debate of EU affairs given that under the conditions we have sketched it is hardly an attractive electoral issue. 
Meanwhile, authorisation and accountability have been reduced by four factors that enhance the independence of national executives:

(4) The increased use of QMV in the Council and bargaining in the Council and the European Council makes it difficult for national parliaments to force governments to enter into detailed ex ante commitments before taking decisions at the European level (Raunio 2009: 327; Ladrech 2009). Parliamentary authorisation of the executive gets proportionately diminished. NPs generally enjoy the right to draft non-binding resolutions on EU affairs (except Denmark and Austria where they are binding). However, in EU affairs their traditional veto power has passed to ministers in the Council and so become non-existent.

(5) National governments represent their countries in EU negotiations, resulting in informational asymmetries between the executive branch and the legislature that likewise constrain parliamentary control and influence.

(6) Parliaments - and particularly the opposition - do not debate government actions and positions in EU-related affairs to the same degree as in domestic politics. Plenary debates of EU-related issues are comparatively rare (Raunio 2009: 320). These matters tend to be delegated to the European Affairs Committees, whose discussions are harder for the electorate to follow given that in many MS their proceedings are not open to the public. The German government even proposed to circumvent parliamentary debate of budgetary matters relating to the fiscal compact by handing urgent decisions to a special nine-person committee, though the Federal Constitutional Court ruled this proposal unconstitutional for not respecting the rights of parliament in this area sufficiently - not least because nine persons could not adequately reflect the composition of the Bundestag. ${ }^{2}$

(7) Finally, there is an increased use of instruments and actors over which NPs possess less control than they enjoy over traditional domestic policy instruments. These include governance modes such as the Open Method of Coordination (OMC) in which the European Commission, but potentially also non-elected third parties (experts, civil society organizations) play an important part. In the OMC, no legal role is foreseen for NPs in the official documents that lay out the framework for its functioning. It is typically intergovernmental and rather informal in nature. Research indicates that, by and large, they escape parliamentary scrutiny, and that lines of accountability become increasingly blurred due to unclear chains of delegation and a lack of transparency (Dawson 2009; Kröger 2007).

\footnotetext{
${ }^{2}$ Judgment of 28 February 2 BvE 8/11, $\underline{\text { http://www.bundesverfassungsgericht.de/en/press/bvg12-014.html }}$
} 
Politics, hence parliaments and parties, are deliberately excluded from the governance of this soft law instrument. Consequently, they have shown little inclination to get involved. Meanwhile, the diverse OMCs continue to provide a discursive space at the EU-level that can impact MS' policies through the back door (Offe 2003). The space for partisanship and alternative policy options is thereby drastically reduced, as is the possibility for those concerned to hold respective institutions to account.

Whereas some of these factors reduce the capacity of NPs to debate and influence policies that fall within the competence of the EU, others provide no incentives for parliamentarians and parties to engage with these issues to begin with. Institutionally, studies show that involvement in EU policy-making is ambiguous for each of the three institutional actors within parliaments. The more parties - in particular the opposition - attempt to influence and control the government, thereby seeking to connect them to the electorate, the more they may actually be accused of undermining the 'national interest' by supposedly weakening the government's negotiating position. However, if parties opt for less scrutiny so as to favour effective governance, they may be blamed by the electorate for not representing their constituencies or the 'national interest' while parliamentary involvement 'is reduced to a mere symbolic use of power which in the end undermines the legitimacy of European policymaking' (Auel and Benz 2005: 373). Governments face a similar dilemma. On the one hand, they need to find European solutions in the Council and the European Council. On the other hand, they ought not to alienate their domestic majority and constituency. Besides these more structural dilemmas that parliamentary actors face in EU policy-making, the mere lack of resources necessary to control governments and offer political alternatives also makes it difficult for NPs to live up to their normative role of making governments accountable.

\section{The Response of National Parliaments and Parties}

How have parliaments and parties reacted to these challenges stemming from the EU? NPs have sought to institutionally counter their weakened role in the context of EU policy-making. Since the 1990s, the goal of NP was threefold: to obtain comprehensive information about EU policy processes by their governments, to enhance their own institutional capacity to handle the information (resulting in the setting up of European Affairs Committees and the introduction of scrutiny procedures in all MS), and to establish participation rights in EU affairs vis-à-vis the government, the mandating effect of which differs substantially between 
MS (Auel 2005: 308). The most visible adaptation to date has been the establishment of European Affairs Committees in all the MS' parliaments. Their main function is to coordinate parliamentary scrutiny of the government in EU matters. While this potentially strengthens the authorization and accountability function of parliaments, helping them and parties to reduce information asymmetries (Benz 2005: 515) and thereby influence and control governments better, we noted how moving debates to special committees may also weaken the expression of disagreements and the exercise of control.

More recently, however, political concern with de-parliamentarization and the legitimacy of further integration has prompted the introduction of the 'early warning system' with regard to potential infringements of subsidiarity and proportionality in the Lisbon Treaty. Under Protocol 2 of the LT, NPs can send the Commission reasoned opinions on draft EU legislative acts stating why they consider them to breach the principle of subsidiarity. The Commission then sends NPs responses to their reasoned opinions. The so-called 'yellow card' entails that if a third of NPs object to a legislative proposal of the Commission, then it must reconsider the proposal. Furthermore, they may issue an 'orange card' and stop a legislative proposal if a majority of NPs oppose it and either the Council or the EP agrees under the codecision procedure. Besides the early warning system, NPs also engage in the so-called informal political dialogue (IPD) with the Commission in which they can express more substantial opinions on proposed policies. However, it has been doubted if either power is likely to enhance parliamentary debate and control. According to Tapio Raunio, it

ignores the fusion of the executive and legislative branches in parliamentary democracies, which makes it very unlikely that the parliament would adopt a different position than the government. Secondly, violations of the subsidiarity principle are by most accounts very rare, with national governments and parliaments until now hardly ever voicing complaints about the EU institutions overstepping the limits of their formal competencies. Related to that is the improbability that the sufficient number of national parliaments would agree on the same legislative proposal violating the subsidiarity principle. And, finally, the process is an entirely voluntary one, and it is very likely that parliaments will use it with varying degrees of interest (Raunio 2009: 325).

These predictions are to some extent confirmed by a recent assessment by COSAC of the use parliaments have made of these new mechanisms during the 18 months following the LT. ${ }^{3}$ The report shows that the large majority of parliaments / Chambers (P/Cs) are satisfied with their internal subsidiarity control mechanisms, many of which were adopted as a

\footnotetext{
${ }^{3}$ See http://www.cosac.eu/en/documents/biannual/
} 
response to the new mechanisms of the LT. ${ }^{4}$ Between December 2009 and August 2011, 19 $\mathrm{P} / \mathrm{Cs}$ had adopted either none or one reasoned opinion. By contrast, in Poland the parliament and second Chamber had adopted seven and eight reasoned opinions respectively, with the remaining P/Cs somewhere in between (see graph 1).

\section{Graph 1}

\begin{tabular}{|l|l|}
\hline $\begin{array}{l}\text { Number of reasoned } \\
\text { opinions }\end{array}$ & $\begin{array}{l}\text { Number of } \\
\text { Parliaments/Chambers }\end{array}$ \\
\hline 0 & 10 \\
\hline 1 & 9 \\
\hline 2 & 4 \\
\hline 3 & 8 \\
\hline 4 & 1 \\
\hline 5 & 2 \\
\hline 6 & 0 \\
\hline 7 & 1 \\
\hline 8 & 1 \\
\hline
\end{tabular}

Source: own calculations

In half of the cases where a reasoned opinion was adopted, the P/Cs did so because of a perceived lack of a legal basis and / or lack of, or insufficient, subsidiarity justification. However, the P/Cs noted that the Commission rarely met its self-imposed three-month timelimit for replying to reasoned opinions, which generally took 4-6 months. More importantly, only a small minority of P/Cs (4) was satisfied with the Commission's reply, while several $\mathrm{P} / \mathrm{Cs}$ criticized its quality, regarding it as too short and general. In fact, many believed the Commission sends the same standardized general response to all reasoned opinions. Still more worryingly, only one Chamber thought its concern had been taken up in the Commission's subsequent legislative proposal, whereas all the other P/Cs saw no evidence of it having done so. P/Cs had different assessments of the eight-week period they are given to check the compliance of EU draft legislative acts with the principle of subsidiarity. $12 \mathrm{P} / \mathrm{Cs}$ found it satisfactory, $14 \mathrm{P} / \mathrm{Cs}$, while admitting it could be done, expressed diverse reservations about it, while 8 regarded the time frame as simply too tight ${ }^{5}$.

As we noted, 'reasoned opinions' only apply to checks on subsidiarity and proportionality. P/Cs, therefore, have made increasing use of the so-called Informal Political Dialogue (also known as 'the Barroso initiative') which was launched in 2006. Its goal was to encourage NPs to express their opinions on the Commission's initiatives not only in relation to

\footnotetext{
${ }^{4}$ There are 14 unicameral Parliaments and 13 bicameral Parliaments in the EU, making 40 parliamentary chambers (called in the report Parliament and Chamber - for the first and second chamber respectively). COSAC sent a questionnaire to the committee of each chamber. Given that 4 bicameral Parliaments submitted only a single response the $\mathrm{N}=36$.

${ }^{5}$ Two P/Cs did not provide an answer to this question.
} 
the principle of subsidiarity but also in a more general way. Overall, this instrument is more used than the 'reasoned opinion', with 565 opinions or reports issued since 2006. However, its usage differs greatly, with 9 P/Cs having never used it, whereas the Portuguese have used it 220 times.

The record seems mixed, therefore. Clearly, a number of parliaments are anxious to employ their new powers, have become better informed, and expressed their disagreements even within a tight time frame. However, their efforts have not enhanced their ability to authorize EU policies and hold them to account because the Commission's response has been largely perfunctory and the threshold for ensuring their concerns are heard is almost impossibly high.

It is less clear how parties have reacted to the influences stemming from the EU. The EU does not impact on political parties directly - it also offers no attractive opportunity structure for them to get engaged with EU politics (Ladrech 2009). The influence on political parties is, therefore, indirect. However, due to European Treaty obligations and the reduction of the policy repertoire, parties have tended to converge on centrist policies, contributing to the increasing dilution of the traditional left-right divide. As a result, they offer voters fewer electoral alternatives, which in turn contributes to increasing voter volatility and decreasing voter turnout. Reasonable disagreement is foreclosed as is responsiveness as parties feel required to pursue the 'responsible' policies that follow from their European commitments, as was recently witnessed in parliamentary debates and decisions in Greece and other MS in dealing with the Euro-crisis (Mair 2009, 2011).

This problem is in part home-made. Despite the increase in EU policy competence, parties have not really engaged in internal changes that would produce better ex ante or ex post mechanisms of control of the executive and more expertise within the party to become a competent interlocutor on EU matters (Ladrech 2007). In regard to the first point, 'cooperation takes place behind closed doors' (Auel und Benz 2005: 390), contributing to the blurring of responsibilities between opposition and majority parties. To strengthen the national negotiation position, consensus between governing parties is sought in camera, implying that the public is not offered political alternatives (Auel and Benz 2005 379). Opposition parties, in turn, are unlikely to demand plenary debates about the EU given that they either have similar preferences to those of the government or lack more coherent approaches to the EU (Raunio 2009: 320). In regard to the second point, the EU offers party élites too little to make it a priority: it provides no votes that could translate into power and office-holding, no additional resources, no direct influence on EU policies, while EP 
elections remain largely second-order, Therefore, it is unclear how the conflicting positions that exist over Europe can be articulated if parties decide that the EU should not be contested.

Some analysts have objected that none of this matters. For example, Andrew Moravcsik has questioned the extent of EU decision-making, arguing that it only affects 10$20 \%$ of domestic legislation, mostly in areas with low electoral salience $(2001,2008)$. Moreover, he insists that there is 'tight national oversight' not just of treaty amendments, but also due to the need to secure approval from a weighted $2 / 3$ majority in the Council of Ministers and 'transposition into national law by national bureaucracies or parliaments' (Moravcsik 2008: 334). Our analysis suggests that this national oversight is looser and has fewer democratic credentials than he maintains. It might still be argued, though, as Majone (2001) and - in recent work - Moravcsik (in Keohane, Macedo and Moravcsik 2009) too has claimed, that in the main policy areas covered by the EU there are good reasons for sidelining government 'by' the people so as to improve government 'for' the people in the context of a global economy. For example, Keohane et al. contend that upholding free trade agreements against the protests of producer groups seeking to preserve various protectionist policies - be they from labour or capital - has been generally beneficial to national economies and domestic consumers (Keohane, Macedo and Moravcsik 2009: 14). Such moves reflect the traditional constitutional constraints that operate in most democratic states to prevent the rentseeking behaviour of special interests and factions from producing outcomes that subvert both the public interest and political equality (Keohane, Macedo and Moravcsik 2009: 6-7, 9-10). Yet, as they also grant (Keohane, Macedo and Moravcsik 2009: 16), it will be an empirical and, it should be added, a normative issue when such arguments apply, that to some degree can only be decided on a case by case basis. For example, the costs and benefits over the long-term of local agreements to protect wage levels, working conditions and job security, of the kind at issue in Laval, are difficult matters to assess - not least because there may not be an agreed metric of what the 'best' policy outcome would be. Constraining political debate of such matters may not only be unjustified, removing from political control issues that are subject to reasonable disagreement, but also create the very distortions such moves seek to avoid if the effect of the constraint is to reduce equality of access in ways that privilege certain well-placed yet unrepresentative groups. Unsurprisingly, for instance, the lobbying and legal avenues offered by the EU have been exploited disproportionately by corporate bodies to strengthen the position of those companies likely to benefit from deregulation at the national level (Coen and Thatcher 2005; Harding 1992). In which case, the need for 'tight national oversight' remains vital and it's undermining a matter of concern. 


\section{Conclusion}

This paper has explored the ability of NPs to fulfil the role assigned them by the LT's understanding of representative democracy. We established how political equality links with reasonable disagreement and public control to provide the three core ideas underpinning representative democracy and noted how NPs and parties realise these three criteria. However, our analysis reveals that in various respects European decision-making structures have empowered both national executives and EU level decision-makers, such as the ECJ and the Commission, in ways that diminish opportunities for either NPs or parties to express reasonable disagreement and exercise control over EU level policies. On the one hand, EU decisions become either de facto or de jure beyond disagreement or debate. Parliaments and parties may lack relevant information, be wary of undermining the bargaining position of governments, or worry they may open up intra-party rifts and so keep European issues off the electoral and parliamentary agenda. Meanwhile, the constitutionalization of the Treaties by the ECJ has effectively removed certain aspects of the acquis off the political agenda. National governments, parliaments and courts must simply implement EU legislation as interpreted by the ECJ. On the other hand, and partly as a result of the diminished scope for reasonable debate about the EU, effective control has become more problematic. Not only have certain policy areas effectively migrated upwards to the European level, but also it has become increasingly hard to hold national actors accountable for what they do at the EU level. Either their precise involvement remains unknown, or their own power has been limited by such changes as the move to QMV. Finally, parties, are for different reasons not ready or not willing to engage in the politicization of European integration, furthering hampering the contestation of EU policies.

Consequently, citizens' preferences about the EU are not properly represented,Yet, if EU policies have been removed from political debate and depoliticized, then citizens not only cannot hold their government and representatives to account for them, but also cannot organize opposition to them within the political system. In which case, policy opposition can turn into polity opposition (Mair 2007) as the growing electoral successes of extreme-right, euro sceptical parties testifies. Without channels for reasonable disagreement on EU matters, the risk of unreasonable disagreement increases.

We have doubted that the powers allotted to NPs by the LT can make much difference. They attempt to give parliaments a more informed role in debating EU affairs by providing 
more information and encouraging the development of parliamentary European Affairs committees and cooperation between them. They also seek to empower parliaments by giving them a collective competence over the EU's own competences. Yet both powers are too weak and the threshold for the yellow and orange cards is impossibly high. Moreover, the rights and responsibilities the LT assigns to NPs mostly deal with government-related functions of parliaments. At best, NPs are to act as the gatekeepers of European integration, rather than performing their traditional function of shaping policies through legislative acts.

Is one effect of increasing EU competences and influence in policy-making that European citizens learn to live with an absence of input-oriented democracy (Sprungk 2011: 2)? Are we moving, as some authors contend, to an 'audience democracy'? We doubt it. The mass protests in Greece, Ireland and Spain against the public sector cuts resulting from the Eurozone crisis suggest a large number of citizens remain unwilling to accept that governments and parties simply should adjust to whatever the EU requires of them and that states become 'polities without politics'. If parties and governments continue to ignore the desire of citizens to engage in political processes, we are likely to continue to witness a destructuring of the party system at the national level (Bartolini 2005), and an increasing disaffection with representation through parties rather than with democracy itself. Yet, as we saw and the LT affirms, parties and parliaments have proved structurally necessary to realising political equality within mass representative democracies. So far, no realistic alternative has emerged to ensure all views are as fairly represented, their differences as reasonably debated to obtain the advantages of democratic deliberation, and governments as effectively controlled through being made indirectly and directly accountable to citizens on a basis likely to accord them equal concern and respect. Any weakening of this system, therefore, remains worrisome for democracy in the EU.

Whether strengthening EU level democracy and with it political union might provide an answer lies outside the scope of this paper. The handling of the euro crisis is ambivalent in this regard. Thus far, the EP has been conspicuous by its absence in debates on this issue. By contrast, the LTs provisions and the crisis have presented NPs with an opportunity to strengthen representative democracy and political equality within and because of the EU. So far, they have failed to take full advantage of this situation. It remains to be seen whether they will seize this chance to enhance the legitimacy of EU policies in the eyes of European citizens in the future. 


\section{References}

Andersen, S.S. and T.R. Burns, 1996, The European Union and the Erosion of Parliamentary Democracy: A Study of Post-parliamentary Governance, in S.S. Andersen and K.A. Eliassen (eds.), The European Union: How Democratic Is It? (London: Sage), 227-51.

Auel, K., 2005, Introduction: The Europeanisation of parliamentary democracy, The Journal of Legislative Studies, 11 (3-4): 303-318.

Auel, K. and A. Benz, 2005, The Politics of Adaptation: The Europeanisation of National Parliamentary Systems, The Journal of Legislative Studies, 11 (3-4): 372-393

Bartolini, S., 2005, Restructuring Europe. Centre formation, system building and political structuring between the nation-state and the European Union (Oxford: Oxford University Press).

Bellamy, R., 2010, Democracy without Democracy? Can the EU's Democratic 'Outputs' be Separated from the Democratic 'Inputs' Provided by Competitive Parties and Majority Rule?, Journal of European Public Policy, 17: 2-19.

Benz, A., 2005, Conclusion: Linking Research on Europeanisation and National Parliaments, The Journal of Legislative Studies, 11 (3-4): 508-521.

Christiano, T., 1996, The Rule of the Many: Fundamental Issues in Democratic Theory. (Boulder: Westview Press).

Coen D. and M. Thatcher, 2005, The New Governance of Markets and Non-Majoritarian Regulators, Governance, 18: 329-46

Crouch, C., 2004, Post-Democracy (Cambridge: Polity Press).

Dawson, M., 2009, EU Law 'Transformed'? Evaluating Accountability and Subsidiarity in the 'Streamlined' OMC for Social Inclusion and Social Protection. In: Kröger, Sandra (ed.) What We Have learnt: Advances, Pitfalls and Remaining Questions of OMC Research. European Integration Online Papers, special issue 1 (13).

Harding, C., 1992, Who Goes to Court? An Analysis of Litigation Against the European Community, European Law Review, 17 (1): 105-25.

Hix, S., 2008, What's Wrong with the European Union and How to Fix It (Cambridge: Polity).

Hobson, C., 2008, Revolution, Representation and the Foundations of Modern Democracy'. European Journal of Political Theory 7(4): 449-471.

Joerges, C., 2010, The Rechtsstaat and Social Europe: How a Classical Tension Resurfaces in the European Integration Process, Comparative Sociology 9 (1): 65-85.

Keohane, R.O, Macedo, S. and A. Moravcsik 2009 'Democracy-Enhancing Mulitilateralism', International Organisation 63, 1-31.

Kröger, S., 2007, The End of Democracy as We Know It? The Legitimacy Deficits of Bureaucratic Social Policy Governance. Journal of European Integration 29 (5): 565-582. 
Ladrech, R., 2009, Europeanization and Political Parties, Living Reviews in European Governance 4 (1).

Ladrech, R., 2007, National Political Parties and European Governance: The Consequences of 'Missing in Action'. West European Politics, 30 (5): 945-960.

Lord, C. and J. Pollak, 2010, The EU's Many Representative Modes: Colliding? Cohering?' Journal of European Public Policy, 17 (1): 117-136.

Mair, P., 2011, Smaghi vs. the Parties: Representative Government and Institutional Constraints, Paper prepared for the Conference on Democracy in Straightjackets: Politics in an Age of Permanent Austerity, Ringberg Castle, Munich, March 23-26, 2011.

Mair, P., 2009, Representative versus Responsible Government. MPIfG Working Paper 09/8. Cologne: Max Planck Institute for the Study of Societies.

Mair, P., 2007, Political Parties and Party Systems, in Graziano, Paolo, Vink, Maarten P. (eds.) Europeanization: New Research Agendas. (Palgrave Macmillan, Basingstoke), 154-166.

Manin, B., 1997, The Principles of Representative Government. (Cambridge: Cambridge University Press).

May, K., 1952, A Set of Independent, Necessary and Sufficient Conditions for Simple Majority Decision. Econometrica, 10, 680-84

McGann, A. J., 2004, The Tyranny of the Supermajority: How Majority Rule Protects Minorities. Journal of Theoretical Politics 16, 53-77

Majone, G., 2001, Nonmajoritarian Institutions and the Limits of Democratic Governance: a Political Transaction Cost Approach, Journal of Institutional and Theoretical Economics, 157 (1): 57 78.

Maurer, A. and Wessels, W., (eds.), 2001, National Parliaments on their Ways to Europe: Losers or Latecomers? (Baden-Baden: Nomos).

Mittag, J'urgen, Wessels, Wolfgang, 2003, 'The 'One' and the 'Fifteen'? The Member States between Procedural Adaptation and Structure Revolution', in , J"urgen Mittag and Wolfgang Wessels (Eds), Fifteen into One? The European Union and its Member States, Manchester University Press, Manchester, , pp.413-454.

Moravcsik, A., 2008, The Myth of Europe's "Democratic Deficit", Intereconomics Nov/Dec 2008 33140.

Moravcsik, A., 2002, In Defence of the Democratic Deficit: Reassessing Legitimacy in the EU, Journal of Common Market Studies 40 (4): 603-24.

Neto, O. A. and K. Strøm, 2006, Breaking the Parliamentary Chain of Delegation. British Journal of Political Science 36 (4): 619-43.

Offe, C., 2003, The European Model of 'Social' Capitalism. Can It Survive European Integration? Journal of Political Philosophy 11 (4): 437-469. 
Ordeshook, P. C., 1986, Game Theory and Political Theory. (Cambridge: Cambridge University Press).

Pettit, P., 2004, Depoliticizing Democracy, Ratio, 17, 52-65.

Raunio, T., 2009, National Parliaments and European Integration: What We Know and Agenda for Future Research, The Journal of Legislative Studies, 15 (4): 317-334.

Raunio, T. and S. Hix, 2000, Backbenchers Learn to Fight Back: European Integration and Parliamentary Government. West European Politics, 23 (4): 142-168.

Rawls, J. (1993) Political Liberalism. (New York: Columbia University Press)

Scharpf, F.W., 2011, Monetary Union, Fiscal Crisis and the Preemption of Democracy, LES Paper No. $36 / 2011$

Scharpf, F., 2009, Legitimacy in the Multilevel European Polity, European Political Science Review, 1: $173-204$.

Scharpf, F., 1999, Governing in Europe: Effective and Democratic?, (Oxford: Oxford University Press).

Schattschneider, E. E., 1942, Party Government. (New York: Holt, Reinhart \& Winston)

Schmidt, V.A., 2006, Democracy in Europe: The EU and National Polities. (Oxford: Oxford University Press).

Schmidt, V.A., 1999, 'European "Federalism" and its Encroachments on National Institutions', Publius, 29/1: 19-44.

Schmitter, P., 2009, Re-representing Representation, Government and Opposition, 44, (4): 476-490.

Sprungk, C., 2011, Transforming Democracy? The Europeanization of National Parliaments in Old and New MS. Paper presented at the Council for European Studies conference, 20-22 June 2011, Barcelona.

Strøm, K., Müller, W.C. and T. Bergman (eds.), 2003, Delegation and Accountability in Parliamentary Democracies. (Oxford: Oxford University Press).

Waldron, J., 1999, Law and Disagreement. (Oxford: Oxford University Press)

Weale, A., 2007, Democracy. $2^{\text {nd }}$ ed., (Houndmills: Palgrave). 